\author{
M.D. Mednikov, A.S. Sokolitsyn, N.A. Sokolitsyna
}

\title{
CORPORATE BEHAVIOR MODELS OF ENTERPRISES IN A FINANCIAL AND INDUSTRIAL STRUCTURE
}

\author{
М.Д. Медников, А.С. Соколицын, Н.А. Соколицына \\ МОДЕЛИ КОРПОРАТИВНОГО ПОВЕДЕНИЯ ПРЕДПРИЯТИЙ \\ ФИНАНСОВО-ПРОМЫШЛЕННОЙ СТРУКТУРЫ
}

This article is about modeling the corporate behavior of a financial and industrial structure under the present social and economic conditions in our country. Analyzing the publications related to the international and Russian practices in the sphere of forming, functioning and developing industrial corporations one can make a conclusion that they represent one of the ways to integrate financial, industrial and trade capitals by means of a a complex participation system. On the basis of the undertaken analysis we have developed goal-setting concerning the congruence of interests in the enterprisesof vertically-integrated financial and industrial structures based on the suggested interest congruence principles and taking into account the specifics of the present economic conditions in Russia. We have researched the congruence of economic interests of enterprises in vertically integrated structures on the basis of two economic and mathematical models. The support model describes the coordination of the economic interests of each enterprise in a vertically integrated structure in particular with decentralized money distribution. The central one shows the congruence of the economic interests of enterprises in a vertically integrated structure with centralized money. These models form the generalized chart of modeling the corporate behavior of enterprises with a vertically integrated structure. Putting the suggested models into practice allows increasing the effectiveness of these financial and industrial structures due to the synergetic effect from forming interest congruence mechanisms based on optimizing the enterprises' innovation plans in the corporate structure with decentralized and centralized money distribution. Introducing the developed economic and mathematical models and procedures into the corporative management system of financial and industrial structures boosts the effectiveness of their industrial and business operations, creates the necessary conditions for long-term sustainable development. The considered models can be structurally extended by means of including social and economic public interests and their realization within the framework of the public-private partnership system.

CORPORATION; MODEL; SYNERGETIC EFFECT; STRUCTURE; ENTERPRISE.

Применительно к современным социально-экономическим условиям развития нашей страны рассматривается моделирование корпоративного поведения финансово-промышленных структур. Анализ публикаций, касающихся современной практики в области формирования, функционирования и развития промышленных корпоративных структур, показывает, что они представляют собой одну из форм интеграции финансового, промышленного и торгового капитала путем разветвленной системы участия. На основе проведенного анализа разработана постановка задачи согласования интересов предприятий вертикально-интегрированных финансово-промышленных структур, базирующаяся на основе предложенных положений согласования интересов с учетом специфики современных экономических условий развития России. Проведено исследование согласования интересов предприятий вертикальноинтегрированных структур на основе реализации двух экономико-математических моделей. Вспомогательная модель - согласование интересов каждого предприятия вертикально-интегрированной структуры в отдельности при децентрализованном распределении денежных средств. Центральная - согласование интересов предприятий вертикально-интегрированной структуры при централизации их денежных 
средств. На основе этих моделей сформирована обобщенная блок-схема моделирования корпоративного поведения предприятий вертикально-интегрированной финансово-промышленной структуры. Реализация разработанных моделей позволяет повысить эффективность деятельности вертикальноинтегрированных финансово-промышленных структур за счет получения синергетического эффекта посредством формирования механизма согласования экономических интересов, базирующегося на оптимизации инновационных планов предприятий корпоративной структуры при децентрализованном и централизованном распределении денежных средств. Внедрение разработанных экономикоматематических моделей и процедур в систему корпоративного управления финансовопромышленными структурами повышает эффективность их производственно-хозяйственной деятельности, создает необходимые условия для устойчивого долговременного развития. Рассмотренные в статье модели могут быть структурно расширены за счет включения в них социально-экономических интересов государства и их реализации в системе государственно-частного партнерства.

КОРПОРАЦИЯ; МОДЕЛЬ; СИНЕРГЕТИЧЕСКИЙ ЭФФЕКТ; СТРУКТУРА; ПРЕДПРИЯТИЕ.

The timeliness and relevance of the present research consists in the fact that modern economy in each developed country is relies on big firms and companies which actively cooperate with small and medium enterprises, including big corporations, and in order to increase the effectiveness of their functioning and development it is necessary to model their corporate behavior by means of coordinating the economic interests of the enterprises, which in its turn allows obtaining a synergetic effect from uniting the available resources.

The analysis of the publications concerning the international and Russian practices in the field of forming corporations and their functioning shows that big industrial companies are one of the ways of integrating financial, industrial and trade capitals with a complex participation system. For example, [14] shows that the problem of managing large entrepreneurial structures functioning in several industries during a long period of time has been studied insufficiently. Under present day conditions the market model, in which each enterprise is a single independent unit, is economically impractical, as the special features of large companies allow them to adapt more flexibly to the changing economic conditions and toughening competition. The organizational aspects of managing corporate industrial structures are considered in [18]. The problems concerning the efficient implementation of M\&A strategy are addressed as one of the main directions in which large corporate industrial structures develop. Economic and mathematical models of strategic development management for corporate industrial structures have been built in terms of short- and long-term lending. Studying the issues concerning forming, supporting and developing competitive advantages in large corporate structures during economy recession and growth is of special interest [9]. The possible financial sources for the functioning and development of large corporations are given a detailed consideration in [19]. Besides that, [1, 2, $4-7,12,13,19,20]$ present detailed and original research concerning the corresponding aspects of the industrial and business operations of large corporate industrial structures.

Unlike other popular in modern market economy forms of integrating and organizing entrepreneurship (concern, trust, cartel, industrial holding), nowadays a special role belongs to large industrial firms or, in other terms, financial and industrial (industrial and financial) groups (FIGs). Under modern social and economic conditions FIGs are multiprofile and multifunctional structures formed as a result of uniting the capitals of different enterprises, investment, credit and financial institutions, as well as a range of other organizations in order to maximize profit, increase the effectiveness of the functioning and development of FIGs, increase the competitiveness in domestic and external markets, develop technological and cooperation links, boost the economic potential of their members. Legally autonomous firms and enterprises belonging to several branches of economy, banks and other credit bodies, industrial, trade and transport companies are united under the control of the head (Mother) company, i. e. the central company operates in the FIG as the business system center of the group. The central company coordinates the activities of the group members, provides unified accounting, forms a consolidated balance, provides financial statements and performs some banking operations, as well as a 
range of other functions for the group members. So, the FIG members act autonomously in domestic and foreign markets, and the Mother company takes the functions of strategic management in the sphere of investments, production, sales and financial control.

Besides that, the analysis has shown that the basic aim of uniting enterprises into a corporation is cementing their positions in domestic and world markets, raising sustainability, effectiveness and compatibility. Forming corporations can ensure effective spillovers of technologies, qualified personnel and capitals, keeping and developing effective production and cooperation links while making a complex end product, increasing investment and export capacities. Therefore, in modern economy only large capital can normally provide the usage of cutting edge technology and maximum production effectiveness $[6,12,13,15]$.

The analysis of the international and Russian business practices shows that in these industrial firms enterprises often compete in the financial market.

There is usually a lack of finance not only for strategic development, but also for business activities. Despite that, the head (Mother) companies of industrial corporations implement a joint activity investment policy for all enterprises. For this purpose, they accumulate resources and invest them in new projects, as well as in reconstructing and modernizing the enterprises. Due to lack of finance the Head Company chooses the prioritized investment programs for its enterprises, which it will partly finance, and also guarantees getting investments from other sources.

It is a complex issue to select the prioritized investment programs, which actually serve as a plan of technical development and production organization.

Let us consider determining the optimization investment programs for vertically integrated financial and industrial structures.

A vertically integrated financial and industrial structure is a structure which unites a range of enterprises covering all stages of the production process ranging from extracting, manufacturing, assembling enterprises to the distribution network through which the mature product is sold to the end consumer. The organizational unity of all the production chain elements and establishing unified business discipline for all the enterprises and organizations in a vertically integrated structure helps to optimize its industrial and business operations.

Analyzing the functioning and development practices of vertically integrated financial and industrial structures has enabled detecting their special features. For example, [8] considers the peculiarities of managing vertically integrated structures, the positive and negative aspects of their forming, functioning and development are determined. It is argued that they enable harmonizing the economic aims of business development with the social interests of the workforce, business partners and the society in general. Special attention is paid to their usage in petroleum industry. For example, [10] studies the organizational and economic benefits of vertically integrated petroleum companies, which emerged owing to a full-scale change in the management structure, and [3] analyzes the advantages and disadvantages of such companies taking into account the creation and implementation of a new form of business, i. e. a cluster within the framework of regional economic policy. Besides that, it is pointed out that vertically integrated structures are not only economic but also sociotechnical organizations [17].

\section{Background of setting the task concerning the congruence of interests of enterprises in a vertically integrated financial and industrial structure}

Increasing their functioning and development effectiveness usually requires equaling technical (production) capacities of storing, manufacturing and assembling enterprises. Upgrading the enterprises that are lagging behind in order to take them to the level of the average and top ones can be achieved by introducing innovations, which normally requires sufficient money that those enterprises generally lack. Therefore, the increase of the technical level of storing and manufacturing enterprises is usually carried out with the help of the money of the assembling enterprises and the mother company. In this case there arises a very important problem of determining each enterprise's role in the corporative result for profit redistribution between the enterprises and the mother company, which stimulates their effective business. Therefore, this is the problem of coordinating the interests of enterprises and the mother company in financial market. 
Setting the task of enterprises' interest congruence in a vertically integrated

\section{financial and industrial structure}

To coordinate the interests of the enterprises in such a structure we have developed a mechanism based on using the following two economic and mathematical models:

1) support model describing each enterprise's industrial and business operations in particular under the conditions of decentralized resources usage;

2) central model describing the enterprise's industrial and business operations under the conditions of centralized resources usage.

The support model describes the production and financial activities of each enterprise separately, i. e. under the conditions of decentralized resources usage. This model provides support while solving the basic problem, that is equaling the technical level of the corporate structure enterprises throughout the whole technological chain.

The central model describes the enterprise's production and financial activities under the conditions of centralized resources usage. Putting this model into practice allows equaling the technical level of the corporate structure enterprises, i. e. it is the basic model for the interest congruence of corporate structure enterprises.

Forming the centralized money fund of a corporate structure is based on the following general principles:

1. The principles concerning the allocation of financial resources for innovations by enterprises (enterprise reconstruction, equipment modernization), as well as their amount in the centralized fund of the company are considered in advance for the target period.

2. Centralized money fund is formed both by the firm enterprises and the Head Company, as well as other finance sources.

3. The principles of forming (redistributing) the profit from innovations among the firm enterprises and the Head Company are agreed upon beforehand by all those who invest in innovations.

4. The profit is distributed among the investors according to the profit obtained from innovations and the amounts of money invested.
There is no priority when distributing the profit from innovations.

The research into coordinating the interests of enterprises and the central company is based on realizing the following economic and mathematical models $[15,16,18]$.

\section{Determining the interests of each enterprise in a vertically integrated financial and industrial structure in particular under the conditions of decentralized resources usage}

The support model describes each enterprise's production and financial activities separately, i. e. under the conditions of decentralized resources usage and it is as follows:

$$
\begin{gathered}
f(y)=\sum_{j=1}^{n} P_{j} y_{j} \rightarrow \text { max; } \\
\sum_{j=1}^{n} C_{j} y_{j} \leq C ; \\
P_{\beta}+\sum_{j=1}^{n} P_{j} y_{j} \leq P_{\alpha} ; \\
\sum_{j=1}^{n} \Pi_{j} y_{j} / \sum_{j=1}^{n} C_{j} y_{j} \geq r ; \\
y_{j}=\{1,0\},
\end{gathered}
$$

where $y_{j}$ is the figure meaning if innovation $j$ exists in the enterprise's innovation plan $\left(y_{\mathrm{j}}=1\right.$ means planned innovation, $y_{j}=0-$ not planned); $\quad C_{j}$ is planned annual costs of innovation $j$; $\mathrm{C}$ is the enterprise's planned innovation budget; $P_{j}$ is the planned production capacity growth resulting from innovation $j$ shown through the mature corporate product; $P_{\beta}$ is actual production capacity shown through the mature corporate product at the beginning of the target period; $P_{\alpha}$ is the limit of the production capacity shown through the mature corporate product at the end of the target period (this limit is not obligatory); $r$ is acceptable return on costs (rate of return on capital) determined by bank interest rate or average rate of return on capital in the branch.

The economic and organizational meaning of the criteria and limitations is evident and there is no need for any additional comments. This problem is solved by each enterprise independently. 
Research into the congruence of interests of enterprises in vertically integrated financial and industrial structures under the conditions of centralized resources usage

The central model describes the enterprise's production and financial activities under the conditions of centralized resources usage. This model is as follows:

$$
\begin{gathered}
f(x)=\min _{1 \leq i \leq m}\left(P_{i}+\sum_{j=1}^{n_{i}} P_{i j} x_{i j}\right) \rightarrow \max ; \\
\sum_{i=1}^{m} \sum_{j=1}^{n_{i}} C_{i j} x_{i j} \leq C+M ; \\
\sum_{i=1}^{m} \sum_{j=1}^{n_{i}}\left(\Pi_{i j} x_{i j}\right) / \sum_{i=1}^{m} \sum_{j=1}^{n_{i}} C_{i j} x_{i j} \geq r ; \\
x_{i j}=\{1,0\},
\end{gathered}
$$

where $C_{i j}$ is planned annual costs of enterprise $i$ on innovation $j ; C$ is planned innovation budget of the enterprises; $M$ is money spent by the mother company on the enterprises' innovations; $P_{i j}$ is planned annual profit of enterprise $i$ from innovation $j ; C_{i j}$ is planned production capacity growth of enterprise $i$ resulting from innovation $j$ shown through the mature corporate product; $C_{f}$ is actual production capacity of enterprise $i$ shown through the mature corporate product at the beginning of the target period; $r$ is acceptable return on costs (rate of return on capital).

Goal function (6) provides continuous equaling of the production capacities of all enterprises. The model is realized step-by-step according to the following chart that serves to determine the optimal plans of an enterprise in centralized resources usage.

Step 1. Determining the optimal plan for each enterprise with the help of the following model:

$$
\begin{gathered}
f(x)=\mathrm{P}_{\mathrm{i}}+\sum_{j=1}^{n_{i}} P_{i j} y_{i j} \rightarrow \max \\
\sum_{i=1}^{m} \sum_{j=1}^{n_{i}} C_{i j} x_{i j} \leq C+M, i=\overline{1, m} \\
\sum_{i=1}^{m} \sum_{j=1}^{n_{i}} \Pi_{i j} C_{i j} x_{i j} / \sum_{i=1}^{m} \sum_{j=1}^{n_{i}} C_{i j} x_{i j} \geq r, i=\overline{1, m} \\
x_{i j}=\{0,1\}, i=\overline{1, m} .
\end{gathered}
$$

Step 2. Results of (1)-(4) model allow choosing enterprise $i^{*}$ corresponding to the condition

$$
f\left(x_{i^{*}}\right)=\min _{1 \leq i^{*} \leq m}\left(P_{i}+\sum_{j=1}^{n_{i}} P_{i j} x_{i j}\right) \rightarrow \max .
$$

Step 3. For this enterprise let us calculate the costs and subtract them from $C+M$, i. e. calculate the total budget for all the enterprises excluding $i^{*}$

$$
C^{\prime}=C+M-\sum_{j=1}^{n_{i}^{*}} \mathrm{C}_{i^{*} j} x_{i^{*} j} .
$$

Step 4. For these enterprises let us calculate the following profit maximization model

$$
\begin{gathered}
f(x)=\sum_{i=1}^{m} \sum_{j=1}^{n_{i}} \Pi_{i j} x_{i j} \rightarrow \max ; \\
\sum_{i=1}^{m} \sum_{j=1}^{n_{i}} C_{i j} x_{i j} \leq C+M-\sum_{j=1}^{n_{i}^{*}} C_{i^{*} j} x_{i^{*} j} ; \\
\sum_{i=1}^{m} \sum_{j=1}^{n_{i}} \Pi_{i j} x_{i j} / \sum_{i=1}^{m} \sum_{j=1}^{n_{i}} C_{i j} x_{i j} \geq r ; \\
x_{i j}=\{0,1\} .
\end{gathered}
$$
tables.

S te p . Arranging the results into corresponding

The generalized chart describing the process of modeling corporate behavior of the enterprises in a vertically integrated financial and industrial structure is shown in Figure.

This research has yielded the following results including the principally new ones:

1. The proposed mechanisms of coordinating the interests for the vertically-integrated firms are based on optimizing the enterprises' innovation plans with decentralized and centralized money distribution.

2. With decentralized money distribution the optimization model describes each enterprise's production and financial activities separately. With centralized money distribution the production and financial activities of the whole corporation are optimized, each enterprise and the Head Company contributing, which is the most important stimulating factor to increasing its effectiveness. 


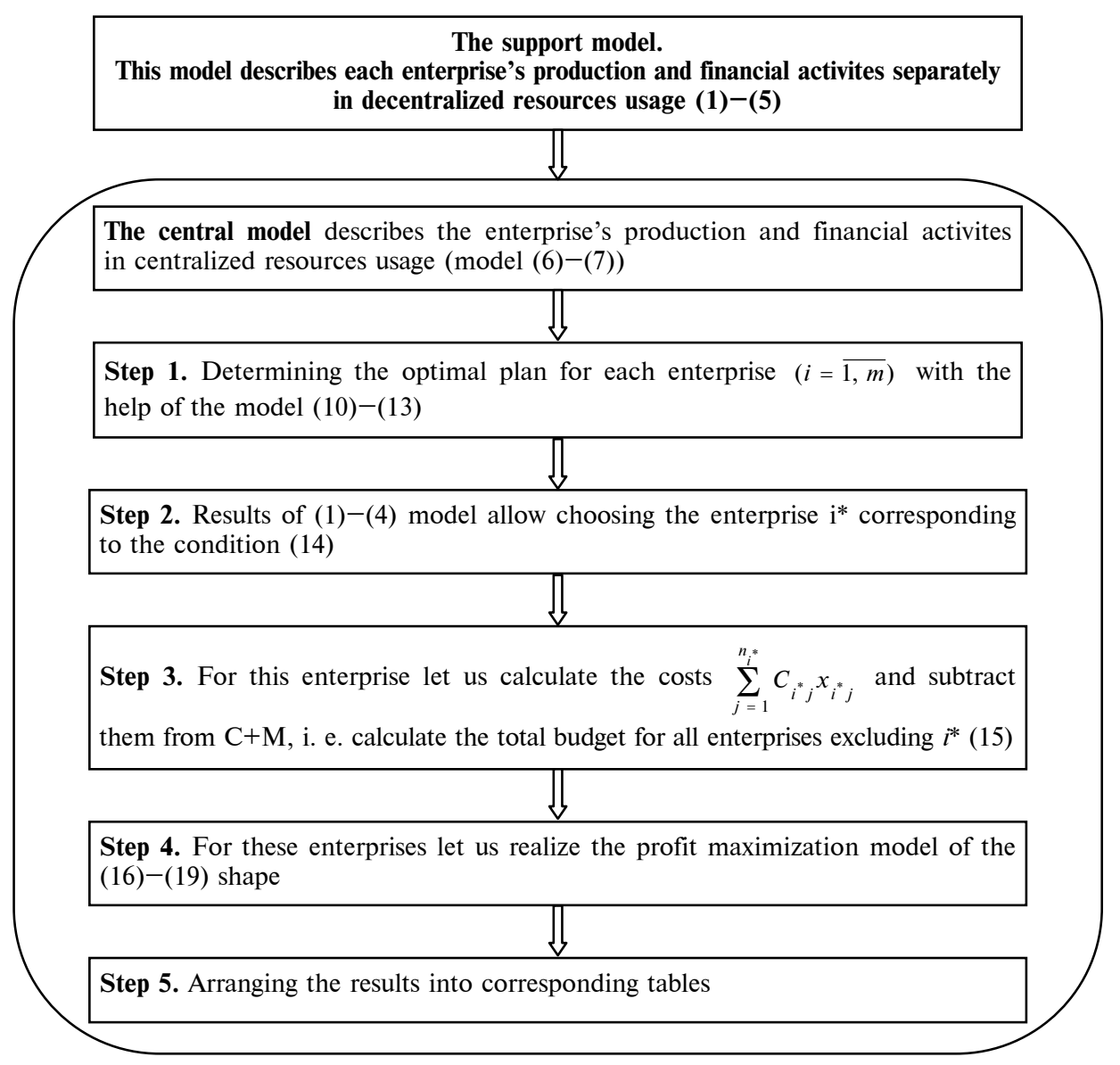

Generalized chartof modeling the corporate behavior of enterprises in a vertically integrated financial and industrial structure

3. It requires special attention that, when put into practice, the science-based approach proposed in the article, which helps to work out the direction and programs of developing the company activities, ensures complexity, coordination of managerial acts and valid economic forecasts.

Introducing the proposed economic and mathematical models, procedures and algorithms into the corporate management system of vertically integrated financial and industrial structures increases the effectiveness of their industrial and business operations, creates the necessary conditions for long-term sustainable development.

The public-private partnership system combined with including social and economic public interests and their implementation can be considered as the main direction for further application of the model regarding the congruence of interests of enterprises in financial and industrial structures under the present day conditions of regional and national economy.

\section{REFERENCES}

1. Babkin A.V., Kudryavtseva T.J., Utkina S.A. Identification and Analysis of Industrial Cluster Structure. World Applied Sciences Journal, 2013, no. 28(10), pp. 1408-1413.

2. Babkin A.V. The problem of decision making on the development of business systems. St. Petersburg State Polytechnical University Journal. Economics, 2013, no. 3(173), pp. 119-130. (rus)

3. Battalova A.A. Vertikal'no-integrirovannaia neftianaia kompaniia - iadro klastera. Neftegazovoe delo. 2012. № 2. URL: http://www.og bus.ru (rus)

4. Glukhov V.V., Balashova E.S., Artemenko E.S., Alekseev A.N. Organizatsiia proizvodstva i marketing. SPb.: Izd-vo Politekhn. un-ta, 2012. (rus) 
5. Glukhov V.V., Mednikov M.D., Korobko S.B. Matematicheskie metody i modeli dlia menedzhmenta: ucheb. posobie dlia vuzov. 2-e izd. SPb.: Lan', 2007. 528 s. (rus)

6. Gradov A.P., Il'in I.V., Suloeva S.B. Strategiia promyshlennogo predpriiatiia: struktura, funktsii, protsessy, vneshniaia sreda. $\mathrm{SPb}$.: Izd. Politekhn. unta, 2008. 551 s. (rus)

7. Deinega V.G. Organizatsiia proizvodstva i sbyta naukoemkoi produktsii gosudarstvennoi korporatsii $\mathrm{v}$ usloviiakh konkurentnykh rynkov. Pod obshch. red. prof. O.I. Kirikova. Voronezh: VGPU, 2009. (rus)

8. Ivanova V.O. Osobennosti menedzhmenta vertikal'nointegrirovannoi kompanii. Rossiiskoe predprinimatel'stvo. 2011. № 11, vyp. (196). S. 55-60. URL: http://www. creativeconomy.ru/arti cles/14301/ (rus)

9. Kak upravliat' konkurentnymi preimushchestvami v periody spada i pod»ema ekonomiki. Pod red. A.P. Gradova. SPb.: Izd-vo Politekhn. un-ta, 2013. 636 s. (rus)

10. Mazur I.I., Shapiro V.D., Ol'derogge N.G., Korotkov E.M. Korporativnyi menedzhment. M.: Omega-L, 2007. 376 s. (rus)

11. Kuznetsova N.A. Preimushchestva vertikal'nointegrirovannykh neftianykh kompanii, kak kompleksnogo preobrazovaniia struktury upravleniia. Sovremennye nauchnye issledovaniia $i$ innovatsii. 2011. № 5. URL: http://web.snauka.ru/issues /2011/09/2767 (rus)

12. Mil'skaia E.A. Strategicheskoe upravlenie innovatsionno-aktivnym predpriiatiem. $\mathrm{SPb}$.: Izd-vo Politekhn. un-ta, 2011. 296 s. (rus)
13. Radaev A.E., Kobzev V.V. Machine building enterprise high tech factory's management conception on basis of simulation modeling. St. Petersburg State Polytechnical University Journal. Economics, 2012, no. 1(139), pp. 128-132. (rus)

14. Sinogeikina E.G. Sovershenstvovanie metodov otsenki vertikal'no-integrirovannykh kompanii: sait Biuro otsenki Labrate.ru. 10 let otsenochnoi deiatel'nosti $v$ Rossii. Itogi $i$ perspektivy : mater. kongressa. URL: http://www.labrate.ru/appraisal_kong ress_4-5_06_2003.htm (rus)

15. Sokolitsyn A.S., Ivanov M.V., Bogomolov Iu.A. Upravlenie diversifikatsiei promyshlennykh predpriiatii - vazhneishii mekhanizm sotsial'no-ekonomicheskogo razvitiia. SPb.: Izd-vo SPbGPU, 2009. 138 s. (rus)

16. Sokolitsyna N.A. Specialities of optimizing coordinating economic interests in the vertically integrated company. St. Petersburg State Polytechnical University Journal. Economics, 2013, no. 2(168), pp. 124-130. (rus)

17. Stanis D.V. Razvitie instituta korporatsii V sovremennoi Rossii. M.: RUDN, 2008. (rus)

18. Industrial enterprise development management A.S. Sokolitsyn, etc. St. Petersburg, Polytechnic University press, 2013. 310 p. (rus)

19. Black F., Scholes M. The Pricing of Options and Corporate Liabilities. Journal of Political Economy, 1973, May-June, vol. 81, no. 3, pp. 637-654.

20. Dixit A.K., Pindyck R.S. Investment under Uncertainty. Princenton University Press, Princenton, NJ, 2001.

\section{СПИСОК ЛИТЕРАТУРЫ}

1. Babkin A.V., Kudryavtseva T.J., Utkina S.A. Identification and Analysis of Industrial Cluster Structure // World Applied Sciences Journal, 2013, no. 28(10), pp. 1408-1413.

2. Бабкин А.В. Задачи принятия решений по развитию предпринимательских систем // Научнотехнические ведомости Санкт-Петербургского государственного политехнического университета. Экономические науки. 2013. № 3(173). С. 119-130.

3. Батталова А.А. Вертикально-интегрированная нефтяная компания - ядро кластера // Нефтегазовое дело. 2012. № 2. URL: http://www.og bus.ru

4. Глухов В.В., Балашова Е.С., Артеменко Е.С., Алексеев А.Н. Организация производства и маркетинг. СПб.: Изд-во Политехн. ун-та, 2012.

5. Глухов В.В., Медников М.Д., Коробко С.Б. Математические методы и модели для менеджмента: учеб. пособие для вузов. 2-е изд. СПб.: Лань, 2007. 528 с.

6. Градов А.П., Ильин И.В., Сулоева С.Б. Стратегия промышленного предприятия: структура, функции, процессы, внешняя среда. СПб.: Изд. Политехн. ун-та, 2008. 551 с.
7. Дейнега В.Г. Организация производства и сбыта наукоемкой продукции государственной корпорации в условиях конкурентных рынков / под общ. ред. проф. О.И. Кирикова. Воронеж: ВГПУ, 2009.

8. Иванова В.О. Особенности менеджмента вертикально-интегрированной компании // Российское предпринимательство. 2011. № 11, вып. (196). C. 55-60. URL: http://www.creativeconomy.ru/arti cles/14301/

9. Как управлять конкурентными преимуществами в периоды спада и подъема экономики / под ред. А.П. Градова. СПб.: Изд-во Политехн. ун-та, 2013. 636 с.

10. Мазур И.И., Шапиро В.Д., Ольдерогге Н.Г., Коротков Э.М. Корпоративный менеджмент. М.: Омега-Л, 2007. 376 с.

11. Кузнецова Н.А. Преимущества вертикально-интегрированных нефтяных компаний, как комплексного преобразования структуры управления // Современные научные исследования и инновации. 2011. № 5. URL: http://web.snauka.ru/issues $/ 2011 / 09 / 2767$ 
12. Мильская Е.А. Стратегическое управление инновационно-активным предприятием. СПб.: Изд-во Политехн. ун-та, 2011. 296 с.

13. Радаев А.Е., Кобзев В.В. Концепция управления высокотехнологичным производством предприятия машиностроения на основе имитационного моделирования // Научно-технические ведомости Санкт-Петербургского государственного политехнического университета. Экономические науки. 2012. № 1(139). С. 128-132.

14. Синогейкина Е.Г. Совершенствование методов оценки вертикально-интегрированных компаний: сайт Бюро оценки Labrate.ru // 10 лет оценочной деятельности в России. Итоги и перспективы : матер. конгресса. URL: http://www.labrate.ru /appraisal_kongress_4-5_06_2003.htm

15. Соколищын А.С., Иванов М.В., Богомолов Ю.А Управление диверсификацией промышленных предприятий - важнейший механизм социально- экономического развития. СПб.: Изд-во СПбГПУ, 2009. 138 c.

16. Соколицына Н.А. Согласование экономических интересов вертикально-интегрированных компаний // Научно-технические ведомости СанктПетербургского государственного политехнического университета. Экономические науки. 2013. № 2(168). C. 124-130.

17. Станис Д.В. Развитие института корпорации в современной России. М.: РУДН, 2008.

18. Управление развитием промышленных предприятий / А.С. Соколицын [и др.]. СПб.: Изд-во Политехн. ун-та, 2013. 310 с.

19. Black F., Scholes M. The Pricing of Options and Corporate Liabilities // Journal of Political Economy, 1973, May-June, vol. 81, no. 3, pp. 637-654.

20. Dixit A.K., Pindyck R.S. Investment under Uncertainty. Princenton University Press, Princenton, NJ, 2001

MEDNIKOV Mikhail D. - Peter the Great St. Petersburg Polytechnic University.

195251. Politechnicheskaya str. 29. St. Petersburg. Russia. E-mail: m_mednikov@mail.ru

МЕДНИКОВ Михаил Дмитриевич - профессор Санкт-Петербургского политехнического университета Петра Великого, доктор экономических наук.

195251, ул. Политехническая, д. 29, Санкт-Петербург, Россия. E-mail: m_mednikov@mail.ru

ALEXANDER Aleksandr S. - St. Petersburg State Polytechnic University.

195251. Politechnicheskaya str. 29. St. Petersburg. Russia. E-mail: alex.sokol1951@yandex.ru

СОКОЛИЦЫН Александр Сергеевич - профессор Санкт-Петербургского государственного политехнического университета, доктор экономических наук.

195251, ул. Политехническая, д. 29, Санкт-Петербург, Россия. E-mail: alex.sokol1951@yandex.ru

SOKOLITSYNA Natal'ia A. - Peter the Great St. Petersburg Polytechnic University.

195251. Politechnicheskaya str. 29. St. Petersburg. Russia. E-mail: natasokoli@yandex.ru

СОКОЛИЦЫНА Наталья Александровна - ведущий специалист департамента стратегического планирования и развития имущественного комплекса Санкт-Петербургского политехнического университета Петра Великого, кандидат экономических наук.

195251, ул. Политехническая, д. 29, Санкт-Петербург, Россия. E-mail: natasokoli@yandex.ru 